\title{
EFEK EKSTRAK BUAH KELOR (Moringa oleifera) TERHADAP PENURUNAN KADAR GULA DARAH MENCIT (Mus musculus)
}

\author{
Effect of the Moringa (Moringa oleifera) Fruit Extract on Lowering Blood Sugar \\ of Mice (Mus musculus)
}

*Ida Ayu Pitriya, Nurdin dan Sri Mulyani Sabang

Pendidikan Kimia/FKIP - Universitas Tadulako, Palu - Indonesia 94118

Recieved 12 December 2016, Revised 13 January 2017, Accepted 15 February 2017

\begin{abstract}
Plant could be potentially as a traditional medicine, relatively safe, and inexpensive, that is from Moringa (Moringa oleifera) fruit, which contains compounds those can lower blood sugar levels. The purpose of this study was to investigate the effect of Moringa fruit extracts on decreasing blood sugar levels of mice and to determine the most effective concentration of the extract. The separation method used was maceration. The animals test used were 15 male mice induced by EDTA. Mice were divided into 5 groups with different treatments. The first, the second, and the third treatments were given Moringa extracts each with a concentration of 10\%, 20\% and 40\%. The fourth treatment was given glibenclamide suspension as a positive control, and the fifth treatment was given $\mathrm{Na}-\mathrm{CMC}$ as a negative control. Data were analyzed using a statistical analysis of variance (ANOVA) test followed by Duncan test. The results showed that Moringa fruit extract lowered blood sugar levels of mice. The means decrease of blood sugar levels for each treatments were $49.67 \mathrm{mg} / \mathrm{dL}$ for the first, $58.33 \mathrm{mg} / \mathrm{dL}$ for the second, $70.33 \mathrm{mg} / \mathrm{dL}$ for the third, $66.67 \mathrm{mg} / \mathrm{dL}$ for the fourth, and $10.00 \mathrm{mg} / \mathrm{dL}$ for the fifth, . This study concluded that the Moringa fruit extract decreased blood sugar levels of mice with the most effective concentration of $10 \%$ and $\alpha=0.05$.
\end{abstract}

Keywords: moringa (Moringa oleifera) Fruit, diabetes mellitus, mice (Mus musculus)

\section{Pendahuluan}

Diabetes mellitus (DM) merupakan salah satu penyakit yang banyak diderita oleh masyarakat Indonesia dengan angka kejadian yang terus meningkat sepanjang tahun. Gejala diabetes adalah adanya rasa haus yang berlebihan, sering kencing terutama malam hari dan berat badan turun dengan cepat. Di samping itu kadang-kadang ada keluhan lemah, kesemutan pada jari tangan dan kaki, cepat lapar, gatal-gatal, penglihatan kabur, gairah seks menurun, dan luka sukar sembuh. Penyakit DM sebagian besar orang merupakan penyakit yang sangat menakutkan, karena akibatnya dari amputasi sampai kematian (Hermanto, 2003) Namun, jika penyakit DM ini diketahui dari awal maka penyakit ini tidak menakutkan, akan tetapi penyakit ini sulit untuk diagnosa karena

\section{*Correspondence:}

Ida Ayu Pitriya

Program Studi Pendidikan Kimia, Fakultas Keguruan dan Ilmu Pendidikan, Universitas Tadulako

email: ayupitriya@gmail.com

Published by Universitas Tadulako 2017 datangnya dengan tenang dan bila dibiarkan akan menyebabkan pasien dalam komplikasi fatal (Ranakusuma, 1987).

PenderitapenyakitDMmengalamigangguan metabolisme pada proses penyerapan gula oleh tubuh, karena tidak dapat melepaskan atau menggunakan insulin secara normal. Insulin adalah hormon yang dilepaskan oleh pankreas, merupakan zat utama yang bertanggung jawab dalam mempertahankan kadar gula darah (Sudoyo dkk., 2006). Pengobatan penyakit DM dapat dilakukan dengan mengontrol kadar darah dengan pemberian obat anti diabetes dan penyuntikan insulin (Verma dkk., 2006). Namun, biaya untuk pengobatannya sangat mahal menyebabkan masyarakat yang memiliki ekonomi yang lemah tidak dapat melakukan pengobatan sehingga dapat memicu salah satu penyebab tingginya kematian bagi penderita. Banyak beredar obat-obat antidiabetes yang dijual di apotek-apotek saat ini. Penggunaan antidiabetes yang tidak tepat dan berlebihan dapat membahayakan kesehatan. 
Misalnya, mengakibatkan gangguan saluran pencernaan (diare, mual, muntah. Dilihat dari efek samping dari penggunaan obatobat antidiabetes dan faktor ekonomi yang masih lemah, menyebabkan masyarakat yang menderita penyakit diabetes mellitus beralih ke pengobatan tradisional karena relatif aman dan murah (Khairuddin, 2009)

Pengobatan tradisional ini, umumnya diperoleh dari bahan-bahan alam. Salah satu tanaman yang berpotensi untuk pengobatan tradisional adalah tanaman kelor (Moringa oleifera) (Krisnadi, 2013). Filtrat buah kelor (Moringa oliefera) berpengaruh tehadap kadar asam urat pada hewan coba tikus putih (rattus norvegicus) strain wistar, dimana hasil penelitian menunjukkan adanya pengaruh pemberian filtrat buah kelor (Moringa oliefera) terhadap kadar asam urat pada tikus putih ( Rattus norvegicus) strain wistar, dimana kadar asam urat rata-rata sebelum pemberian filtrat buah kelor adalah 5,68 mg/dl dan kadar asam urat rata-rata setelah pemberian filtrat buah kelor (Moringa oliefera) adalah $2,76 \mathrm{mg} / \mathrm{dl}$ yang dibuktikan dengan hasil uji Paired T-test menunjukkan bahwa probabilitasnya 0,006 $<0,05$ (Kristinawati, 2013). Senyawa aktif yang terkandung dalam buah kelor adalah alkaloid, flavonoid dan tanin. Senyawa itu dapat menurunkan kadar gula darah (Salam, 2011). Dengan adanya kandungan metabolit sekunder dari buah kelor, mendorong peneliti untuk melakukan penelitian mengenai efek ekstrak buah kelor terhadap penurunan kadar gula darah pada mencit.

Tulisan ini dimaksudkan untuk menginvestigasi efek ekstrak buah kelor dalam menurunkan kadar gula darah mencit dan menentukan konsentrasi paling efektif. Manfaat dari penelitian ini yaitu diharapkan dapat menjadi media visual mata kuliah biokimia lanjut mengenai gangguan metabolisme karbohidrat pada penderita diabetes mellitus dengan pemanfaatan buah kelor untuk meningkatkan sekresi hormon insulin.

\section{Metode}

Alat dan Bahan

Alat dan bahan yang digunakan adalah GlucoDr AGM-2100, strips glucoDr, spoit oral, suntik sonde, ayakan No. 50 mesh, buah kelor (Moringa oleifera) yang diambil di Pasar
Masomba Palu, hewan uji (mencit), alkohol 70\%, Natrium CMC, glibenklamid, etanol $\left(\mathrm{C}_{2} \mathrm{H}_{5} \mathrm{OH}\right)$ (Merck), EDTA (Merck), padatan glukosa $\left(\mathrm{C}_{6} \mathrm{H}_{12} \mathrm{O}_{6}\right)$ (Merck), aquades $\left(\mathrm{H}_{2} \mathrm{O}\right)$, pereaksi mayer (Merck), $\mathrm{HCl}$ pekat (Merck), $\mathrm{H}_{2} \mathrm{SO}_{4}$ pekat (Merck K GaA), dan $\mathrm{FeCl}_{3}($ Merck $K G a A)$.

\section{Cara Kerja \\ Pembuatan ekstrak buah kelor}

Serbuk buah kelor ditambahkan sebanyak 10 gram dan dimasukkan serbuk kelor ke dalam Erlenmeyer. Kemudian ditambahkan 100 mL aquades. Serbuk kelor dimaserasi selama 1 hari dan disheker. Ekstrak hasil maserasi disaring dengan menggunakan pompa vokum. Ekstrak buah kelor 20\% dan 40\% dibuat dengan cara yang sama menggunakan 20 gram dan 40 gram

\section{Uji Pendahuluan Ekstrak Buah Kelor}

Uji pendahuluan yang dilakuakan pada penelitian ini mengikuti prosedur yang telah dilakukan oleh peneliti sebelumnya (Putri, 2015).

\section{Uji Alkaloid}

0,5 gram sampel ditimbang selanjutnya ditambahkan $5 \mathrm{~mL}$ etanol dan dipanaskan kemudian disaring. Filtrat ditambahkan dengan reagen mayer setetes demi setetes apabila menghasilkan endapan yang berwarna putih maka positif mengandung alkaloid.

\section{Uji Flavonoid}

0,5 gram sampel ditimbang kemudian ditambahkan dengan $5 \mathrm{~mL}$ etanol dan dipanaskam kemudian disaring. Filtrat ditambahkan dengan 0,1 gram logam $\mathrm{Mg}$. Jika terbentuk warna kuning jingga maka positif mengandung flavonoid.

\section{Uji Tanin}

0,5 gram sampel ditimbang dan ditambahkan dengan $5 \mathrm{~mL}$ etanol kemudian dipanaskan dan disaring. Filtrat yang terbentuk ditetesi $\mathrm{FeCl}_{3} 1 \%$, apabila terbentuk warna biru tua maka positif mengandung tanin

\section{Pembuatan koloid Na-CMC 1\% b/v}

Koloid Na-CMC 1\% dibuat dengan melarutkan $1 \mathrm{~g} \mathrm{Na-CMC}$ sedikit demi sedikit kedalam $50 \mathrm{~mL}$ air suling panas sambil diaduk 
hingga terbentuk koloid. Volume dicukupkan hingga $100 \mathrm{~mL}$ dengan air suling.

\section{Pembuatan suspensi Glibenklamid}

1 tablet glibenklamid $5 \mathrm{mg}$, digerus dalam lumpang setelah itu ditambahkan dengan koloid Na-CMC 1\% b/v sedikit demi sedikit sambil diaduk hingga homogen. Dimasukkan dalam labu ukur $100 \mathrm{~mL}$ kemudian cukupkan hingga volumenya $100 \mathrm{~mL}$ dengan koloid $\mathrm{Na}-$ CMC $1 \%$.

\section{Pemilihan dan penyiapan Hewan uji}

Hewan uji yang digunakan adalah mencit (Mus musculus) jantan berbadan sehat, berumur 2-3 bulan dengan berat berkisar antara 20-30 gram. Mencit yang digunakan sebanyak 10 ekor dan dibagi dalam 5 kelompok perlakuan.

\section{Perlakuan terhadap hewan uji}

Sebelum diberikan perlakuan hewan uji dipuasakan selama 16 jam, lalu diukur kadar glukos darahnya. Kemudian semua kelompok diinduksikan secara intervena dengan EDTA dengan dosis $150 \mathrm{mg} / \mathrm{kg} \mathrm{BB}$ secara interval vena. Setelah 3 hari, kadar glukosa darah kembali diukur untuk memastikan kadar EDTA masih berfungsi sebagai diabetik eksperimental. Kemudian diberi glukosa 10\% dan selama perlakuan mencit tetap diberi pakan. Mencit dibagi menjadi 5 kelompok dan diberikan perlakuan sebagai berikut:

P1 :perlakuan 1 (pakan + EDTA + glukosa $10 \%+$ ekstrak buah kelor $10 \%+\mathrm{Na}-\mathrm{CMC}) ;$ P2 :perlakuan 2 (pakan + EDTA + glukosa $10 \%+$ ekstrak buah kelor 20\% + Na-CMC); P3 :perlakuan 3 (pakan + EDTA + glukosa $10 \%+$ ekstrak buah kelor 40\%+ Na-CMC); P4 :perlakuan 4 atau kotrol positif (pakan + EDTA + glukosa $10 \%$ + glibenklamid + Na-CMC) dan P5 :perlakuan 5 atau kontrol negatif (pakan + EDTA + glukosa 10\% + Na-CMC)

Setelah diberikan pelakuan semua mencit diistirahatkan ke dalam kandangnya masingmasing dan diberikan makanan dan minuman. Kadar glukosa darah diukur kembali pada hari ke 1,4 dan 7 yaitu pengukuran gula darah akhir

\section{Penentuan kadar glukosa darah}

Sebelum digunakan, glukometer dihidupkan dan strip glukosa dimasukkan ke dalam glukometer. Darah diambil melalui ujung ekor hewan uji (mencit) kemudian diteteskan pada strip glukometer. Dalam waktu 10 detik kadar glukosa darah akan terukur secara otomatis dan hasilnya dapat dibaca pada monitor glukometer.

\section{Ananlisa Data}

Hasil penelitian akan diuji melalui uji statistik analisis sidik ragam (uji F) dengan taraf kepercayaan 95\%. Uji ini digunakan untuk mengetahui perbedaan yang signifikan dari semua perlakuan, dan jika terdapat perbedaan maka pengujian dilanjutkan dengan uji Duncan untuk mengetahui perlakuan mana yang mempunyai perbedaan yang nyata.

\section{Hasil dan Pembahasan}

\section{Uji Senyawa Fitokimia Ekstrak Buah Kelor (Moringa oleifera)}

Hasil pengamatan uji senyawa fitokimia ekstrak buah kelor (Moringa oleifera) tampak pada Tabel 1

Tabel 1. Hasil Uji Senyawa Fitokimia Ekstrak

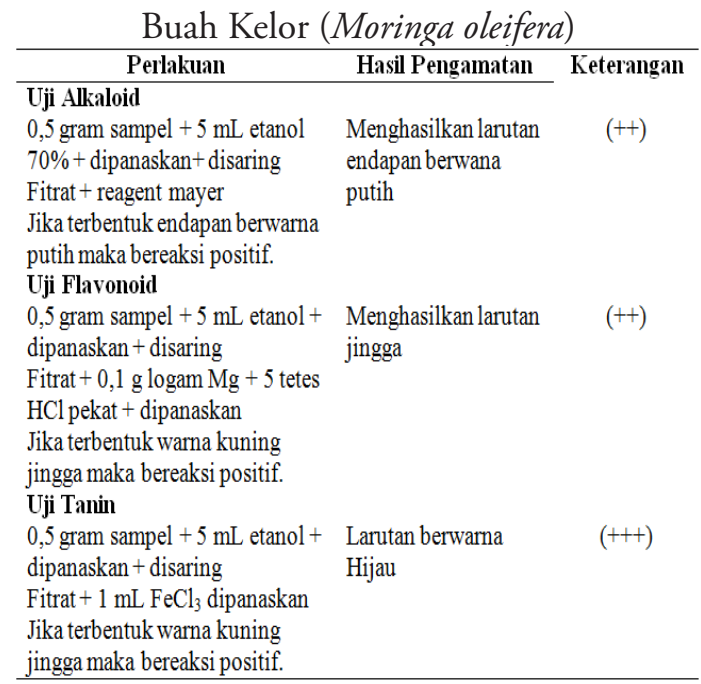

Keterangan : Hasil negatif $=(-)$; Hasil positif lemah $=(+)$; Hasil positif kuat $=(++)$; Hasil positif sangat kuat $=(+++)$

Rerata Kadar Gula Darah Awal, Setelah Induksi, Setelah diberikan Perlakuan dan Penurunan Gula Darah Setelah Pemberian Ekstrak Buah Kelor.

Hasil pengukuran kadar gula darah awal, setelah induksi, setelah diberikan perlakuan dan penurunan gula darah setelah pemberian 
ekstrak buah kelor dapat dilihat pada Tabel 2

Tabel 2. Rerata Kadar Glukosa Darah Awal, Setelah Induksi, Setelah diberikan Perlakuan dan Penurunan Glukosa Darah Pemberian Ekstrak Buah Kelor

\begin{tabular}{llccc}
\hline Perlakuan & $\begin{array}{c}\text { Gula Darah } \\
\text { Awal (mg/dL) }\end{array}$ & $\begin{array}{c}\text { Gula Darah } \\
\text { Setelah Induksi } \\
(\mathrm{mg} / \mathrm{dL})\end{array}$ & $\begin{array}{c}\text { Gula Darah Setelahh } \\
\text { Perlakuan } \\
(\mathrm{mg} / \mathrm{dL})\end{array}$ & $\begin{array}{c}\text { Penurunan Gula } \\
\text { Darah } \\
(\mathrm{mg} / \mathrm{dL})\end{array}$ \\
\hline P1 & 82,67 & 147,33 & 96,33 & 49,67 \\
P2 & 83,33 & 148,33 & 90,00 & 58,33 \\
P3 & 83,67 & 157,33 & 87,00 & 70,33 \\
P4 & 82,33 & 150,33 & 86,67 & 66,67 \\
P5 & 85,67 & 151,33 & 143,00 & 10,00 \\
\hline
\end{tabular}

Keterangan :P1 : pakan + EDTA + glukosa $10 \%+$ ekstrak buah kelor $10 \%+\mathrm{Na}-\mathrm{CMC}$; P2 : pakan + EDTA + glukosa 10\% + ekstrak buah kelor 20\% + Na-CMC; P3 : pakan + EDTA + glukosa $10 \%$ + ekstrak buah kelor $40 \%+\mathrm{Na}-\mathrm{CMC}$; P4 : pakan + EDTA + glukosa $10 \%+$ glibenklimid + Na-CMC; P5 : pakan + EDTA + glukosa 10\% + Na- CMC

Penurunan kadar gula darah pada mencit, dapat diketahui melalui perhitungan selisih antara kadar gula darah setelah diinduksi dengan kadar gula darah setelah pemberian perlakuan. Kemudian dihitung rerata seperti yang tampak pada tabel 2. Grafik yang menunjukkan penurunan gula darah pada mencit terlihat pada Gambar 1

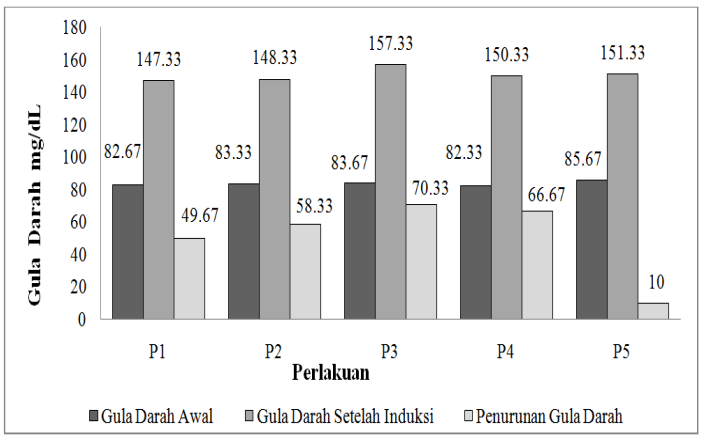

Gambar 1.Rerata Kadar Gula Darah Awal,

Setelah Induksi dengan EDTA dan Penurunan Gula Darah

\section{Hasil Perhitungan Statistik Uji Anava}

Perbedaan yang signifikan antar kelima perlakuan dapat diketahui dengan menggunakan analisis varians (Anova), terlihat pada Tabel 3

Selanjutnya, dilakukan uji Duncan sehingga dapat diperoeh hasil konsentrasi yang paling efektif dalam menurukan kadar gula darah pada mencit. Hal ini dapat dilihat pada Tabel 4

Buah kelor dapat dijadikan sebagai obat
Tabel 3. Hasil Uji Anova Untuk Penurunan Glukosa

\begin{tabular}{cccccc}
\hline & $\begin{array}{c}\text { Sum of } \\
\text { Squares }\end{array}$ & Df & $\begin{array}{c}\text { Maen } \\
\text { Square }\end{array}$ & F & Sig. \\
\hline Between & 7067,333 & 4 & 1766,833 & 10,848 & 0,001 \\
Groups Within & 1628,667 & 10 & 162,867 & & \\
Groups Total & 8696,000 & 14 & & & \\
\hline
\end{tabular}

Tabel 4. Hasil Uji Duncan

\begin{tabular}{cccc}
\hline Perlakuan & N & \multicolumn{2}{c}{ Subset for alpha $=0,05$} \\
\cline { 3 - 4 } & & 1 & 2 \\
\hline P5 & 3 & 10,0000 & \\
P1 & 3 & & 49,6667 \\
P2 & 3 & & 58,3333 \\
P4 & 3 & & 66,6667 \\
P3 & 3 & & 70,3333 \\
Sig. & & 1,000 & 0,094 \\
\hline
\end{tabular}

penurun kadar gula darah pada mencit, harus dilakukan analisis kualitatif senyawa fitokimia pada ekstrak buah kelor. Data pada Tabel 1 dapat dilihat bahwa pada analisis kualitatif senyawa fitokimia pada ekstrak buah kelor mengandung senyawa alkaloid, flavonoid, dan tanin. Uji fitokimia bertujuan untuk mengetahui adanya kandungan senyawa metabolit sekunder yang diharapkan dapat berperan sebagai antihiperglikemia atau antidiabetes. Senyawa aktif bahan alam yang telah diteliti memiliki aktivitas hiperglikemia yaitu alkaloid dan flavonoid (Salam, 2011). Senyawa aktif yang terkandung dalam buah kelor ini dapat menurunkan kadar gula darah. Kadungan flavonoid dan alkaloid ini dapat memperbaiki (regenerasi) sel $\beta$ pankreas yang rusak dan melindungi sel $\beta$ dari kerusakan serta merangsang pelepasan insulin dengan senyawa aktif alkaloid dan flavonoid. Senyawa alkaloid ini mempunyai kemampuan regenerasi sel $\beta$ pankreas yang rusak. Peningkatan sekresi insulin diakibatkan oleh adanya efek perangsang saraf simpatis dari alkaloid yang berefek meningkatkan sekresi insulin (Arjadi \& Susatyo, 2010).

Flavonoid juga memiliki aktifitas hipoglikemik dengan menghambat enzimenzim penting yang berperan dalam pemecahan karbohidrat menjadi monosakarida yang dapat diserap oleh usus yaitu enzim $\alpha$ amilase dan enzim $\alpha$ glukosidase. Enzim glukosidase merupakan enzim yang juga digunakan untuk mengetahui potensi suatu tumbuhan sebagai antidiabetes secara in vitro dengan mekanisme 
penghambatan. Selain itu, Flavonoid mempunyai sifat sebagai antioksidan sehingga dapat melindungi kerusakan sel-sel pankreas dari radikal bebas (Kurniawati dkk., 2010 ).

Tannin dapat mengendapakan protein selaput lendir di permukaann usus halus atau membentuk suatu lapisan yang melindungi usus halus dan membentuk suatu lapisan yang melindungi usus. Tanin terbukti dapat menghambat absorbsi glukosa sehingga laju peningkatkan glukosa darah tidak terlalu tinggi (Mei \& Suyatna, 2006).

Perlakuan selanjutnya yaitu pemberian ekstrak buah kelor untuk menurunkan gula darah dilakukan pada hewan uji mencit (Mus musculus) jantan berbadan sehat, berumur 2-3 bulan dengan berat badan bervariasi antara 25-30 gram. Pemilihan mencit sebagai hewan uji karena ketersediaannya yang cukup tinggi dan cukup peka untuk mewakili manusia dalam penentuan kadar glukosa darah. Mencit memiliki sistem metabolisme dan sistem pencernaan yang relatif sama dengan manusia (Salam, 2011). Mencit jantan digunakan pada penelitian ini karena mencit jantan dapat memberikan hasil penelitian yang lebih stabil karena tidak dipengaruhi oleh adanya siklus mentruasi dan kehamilan seperti pada mencit betina. Mencit jantan juga mempunyai kecepatan metabolisme obat yang lebih cepat dan kondisinya lebih stabil dibandingkan mencit betina (Mangkoewidjojo, 1988).

Mencit terlebih dahulu dipuasakan selama 16 jam sebelum diberikan perlakuaan. Tujuannya adalah untuk meminimalkan faktor makanan yang dapat mempengaruhi kadar gula darah pada mencit, walaupun demikian faktor variasi biologis dari hewan uji tidak dapat dihalangkan, sehingga relatif dapat mempengaruhi hasil, karena terdapat perbedaan glukosa darah awal untuk setiap hewan uji. Setelah dipuasakan, kadar gula darah mencit diukur dengan menggunakan alat GlukoDr. Sehari sebelum perlakuan terhadap hewan uji, terlebih dahulu hewan uji dinduksi dengan menggunakan EDTA (Etil Diamin Tetra Asetat). Fungsi dari larutan EDTA ini adalah untuk menghasilkan kondisi diabetik yang menimbulkan hiperglikemia yang permanen dalam waktu dua sampai tiga hari. Fungsi dari pemberian EDTA adalah untuk menghasilkan kondisi diabetik pada mencit sama halnya dengan diabetogen lainnya, EDTA dapat merusak substansi esensial di dalam sel betapankreas sehingga menyebabkan berkurangnya insulin di dalam sel beta-pankreas (Radiansah, 2013).
Kadar gula darah hewan uji setelah diinduksi EDTA harus lebih dari $120 \mathrm{mg} / \mathrm{dL}$. Syarat untuk terjadinya keadaan hiperglikemia pada hewan uji adalah ketika kadar gula darah hewan uji mencapai $<120 \mathrm{mg} / \mathrm{dL}$, oleh karena itu hewan uji diinduksi pada hari 1,4, dan 7 agar kadar gula darah mencit mengalami kenaikan yang telah dapat memicu terjadinya diabetes (Evasuciany dkk., 2010). Perlakuan selanjutnya adalah pemberian ekstrak buah kelor.

Hasil pada Tabel 2 menunjukkan bahwa nilai rerata kadar gula darah awal mencit berkisar antara $82,33-85,67 \mathrm{mg} / \mathrm{dL}$. Hal ini sesuai bahwa gula darah normal harus berada dalam rentang 60-180 mg/dL (Djojodibroto, 2001). Hasil rerata mencit setelah diinduksi EDTA berkisar 147,33-157,33 mg/dL. Dari hasil Homogenitas kadar gula darah mencit setelah induksi EDTA pada menunjukkan tidak ada perbedaan yang signifikan antar kelompok perlakuan ( $\mathrm{p}>0,05$ atau nilai signifikan $0,427>0,05)$. Dengan demikan, semua kelompok perlakuan layak dibandingkan karena tidak ada perbedaan yang signifikan. Gambar 1 menunjukkan bahwa retara penurunan gula darah tersebut berbeda nyata antara beberapa perlakuan. Perlakuan yang paling berbeda nyata terlihat pada $\mathrm{P} 1$, P2, P3 dan P4 dengan P5 yang menunjukkan bahwa P1 untuk ekstrak buah kelor 10\%, P2 ekstrak buah kelor 20\%, P3 ekstrak buah kelor $40 \%$ dan P4 (kontrol positif) pemberian obat glibenklamid berbeda menurunkan glukosa darah pada mencit dengan P5 (kontrol negatif). Glibenklamid menyebabkan hipoglikemia dengan cara menstimulasi pelepasan insulin dari sel $\beta$ pankreas, meningkatkan pelepasan insulin dari pankreas dan dapat meningkatkan sensitivitas sel-sel sasaran perifer terhadap kadar insulin (Yani, 2014). Penurunan kadar glukosa darah mencit dengan menggunakan ekstrak buah kelor (Moringa oleifera) diduga memiliki kemiripan mekanisme dengan glibenklamid karena keduanya mengandung elektron yang bisa didonorkan pada radikal bebas.

Gambar 1 menunjukkan sedikit terjadi penurunan kadar glukosa darah pada kontrol negatif (P5) karena didukung regenerasi sel $\beta$ pankreas yang sebenarnya induksi aloksan tidak seluruhnya merusak sel $\beta$ pankreas sehingga masih terdapat insulin yang masih bisa dieksresi. Meskipun terjadi sedikit penurunan namun kadar glukosa darah pada hewan uji 
masih dikatakan diabetes. Kontrol positif terjadi penurunan yang signifikan karena glibenklamid merupakan obat antidiabetik oral golongan sulfonilurea yang mekanisme kerjanya menstimulasi sel $\beta$ pankreas untuk melepaskan sekresi insulin. Selain merangsang sekresi insulin, dalam memberikan efek penurunan kadar glukosa darah dapat melalui jalan lain dengan memperbaiki kerusakan akibat mekanisme aloksan dimana mengganggu homeostatis intraseluler menyebabkan depolarisasi sel $\beta$ pankreas dan membuka kanal kalsium sehingga terjadi gangguan sensitivitas insulin (Nugroho, 2006)

Tabel 3 menunjukkan bahwa antar perlakuan mempunyai nilai signifikan 0,001 < $\alpha=0,05$. Hal ini berarti terdapat penurunan glukosa bermakna diantara kelima perlakuan. Hasil uji Anova didapatkan Fhitung $=10,848$ lebih besar dibandingkan dengan Ftabel 5\% $=2,87$. Hal ini menunjukkan terjadinya perbedaan yang signifikan antar kelompok. Selanjutnya, dilakukan uji Duncan sehingga dapat diperoeh hasil konsentrasi yang paling efektif dalam menurukan kadar glukosa darah pada mencit. Hasil perhitungan uji statistik uji Duncan untuk penurunan glukosa dengan taraf signifikan $5 \%$ di atas menunjukkan bahwa perlakuan pada kontrol negatif (P5) yaitu perlakuan tanpa ekstrak dengan keempat perlakuan lainnya memiliki perbedaan yang signifikan. Perlakuan obat glibenklamid dengan ekstrak 10\%, 20\% dan 40\% tidak terjadi perbedaan yang signifikan. Berarti yang konsentrasi ekstrak yang paling efektif dalam menurunkan gula darah adalah perlakuan dengan pemberian konsentrasi ekstrak buah kelor $10 \%$. Hal ini disebabkan karena kandungan biaoaktif yang terdapat dalam buah kelor, yaitu kandungan alkaloid, flavonoid, dan tanin. Mekanisme penyembuhan penyakit DM oleh ektrak tumbuhan tertentu berkaitan erat dengan kandungan flavonoid dalam tumbuhan tersebut. Flavonoid diduga berperan dalam meingkatkan aktivitas enzim antioksidan dan mampu meregenerasi sel-sel $\beta$ pankreas yang rusak sehingga defisiensi insulin dapat diatasi. Flavonoid diduga juga dapat memperbaiki sensitifitas reseptor insulin, sehingga memberikan efek yang menguntungkan bagi penderita diabetes mellitus (Marianne dkk., 2011). Selain itu, flavonoid berperan sebagai antioksidan yang dapat melindungi dan menangkap radikal-radikal bebas yang terdapat didalam tubuh. Radikal bebas merupakan salah satu penyebab terjadinya diabetes melitus (Middleton dkk., 2000)

Senyawa alkaloid memiliki kemampuan untuk menghentikan reaksi rantai radikal bebas secara efisien. Senyawa radikal turunan dari senyawa amina ini memiliki tahap terminasi yang sangat lama. Alkaloid dan tanin juga dapat menghambat absorpsi glukosa di usus. Sehingga adanya flavonoid, alkaloid dan tannin memberikan efek yang menguntungkan pada keadaan diabetes melitus. Tanin berfungsi sebagai antioksidan karena kemampuannya dalam menangkap radikal bebas, menghambat radikal bebas, dan tumor (Agustanti, 2008). Senyawa ini juga mempunyai aktifitas hipoglikemia yaitu dengan meningkatkan glikogenesis. Selain itu tanin juga berfungsi sebagai astringent atau pengkhelat yang dapat mengkerutkan membran epitel usus halus sehingga mengurangi penyerapan sari makanan akibatnya menghambat asupan gula dan laju peningkatan gula darah tidak terlalu tinggi (Monica, 2006). Tanin dapat mengendapakan protein selaput lendir di permukaan usus halus atau membentuk suatu lapisan yang melindungi usus halus dan membentuk suatu lapisan yang melindungi usus. Tanin terbukti dapat menghambat absorbsi glukosa sehingga laju peningkatkan glukosa darah tidak terlalu tinggi. Tanin menghambat kerja enzim $\alpha$-glukosidase didlam usus untuk mengubah disakarida menjadi glukosa (Mei \& Suyatna, 2006).Tanin merupakan antioksidan potensial dapat memperbaiki keadaan oksidatif patologis dari situasi diabetes (Kumari \& Jain, 2012)

\section{Kesimpulan}

Ekstrak buah kelor dapat menurunkan kadar gula darah mencit. Rata-rata penurunan gula darah pada perlakuan I dengan ekstrak buah kelor $10 \%$ sebesar $49,67 \mathrm{mg} / \mathrm{dL}$, perlakuan II dengan ekstrak buah kelor 20\% sebesar 58,33 $\mathrm{mg} / \mathrm{dL}$, perlakuan III dengan ekstrak buah kelor $40 \%$ sebesar 70,33 mg/dL, perlakuan IV dengan obat glibenklamid sebesar $66,67 \mathrm{mg} / \mathrm{dL}$ dan perlakuan $V$ tanpa perlakuan sebesar 10,00 $\mathrm{mg} / \mathrm{dL}$. Hasil penelitian menunjukkan bahwa ekstrak buah kelor dapat menurunkan kadar gula darah mencit dengan konsetrasi paling efektif $10 \%$ dengan $\alpha=0,05$. 


\section{Ucapan Terima Kasih}

Penulis mengucapkan terima kasih kepada Idha Kesuma Utami selaku laboran Laboratorium Agroteknologi Fakultas Pertanian Universitas Tadulako yang telah menuntun selama penelitian.

\section{Referensi}

Agustanti, L. (2008). Potensi daun sirih merah (piper crocatum) sebagai aktivator enzim glukosa oksidase. Bogor: Institut Pertanian Bogor.

Arjadi, F., \& Susatyo, P. (2010). Islet of langerhans regeneration in diabetc white rats (rattus norvegicu) after giving decocted pulp of mahkota dewa (phaleria macrocarp (scheff.) boerl). Jurnal of Medical Faculy Jendral Soedirman University, 2(2), 117-126.

Djojodibroto, D. (2001). Seluk beluk pemeriksaan kesehatan, general medical chek up. Jakarta: Pustaka Populer Obor.

Evasuciany, E., Delima, E. R., \& Boen, R. (2010). The effect of morinda citrifolia L. ethanol extract on blood in alloxan induced male mice swiss webster strain. Jurnal Medika Planta, 1(1), 87-92.

Hermanto, N. (2003). Menaklukan penyakit bersama mahkota dewa. Jakarta: Argomedia Pustaka.

Khairuddin. (2009). Kajian rasionalitas penggunaan antibiotik pada pasien yang dirawat pada bangsal penyakit dalam di RSUP Dr.Kariadi Semarang tahun 2008. Semarang: Fakultas Kedokteran Universitas Diponegoro,

Krisnadi, A. (2013). Kelor Super Nutrisi. Diakses dari kelorina.com/ebook.pdf, 20 November 2014.

Kristinawati, E. (2013). Pengaruh pemberian filtrat buah kelor (moringa oliefera) tehadap kadar asam urat pada hewan coba tikus putih (rattus norvegicus) strain wistar. Jurnal Kesehatan, 7(6), 27-31.

Kumari, M., \& Jain, S. (2012). Tannins: An antinutrient with positive effect to manage diabetes. Research Journal of Recent Sciences, 1(12), 70-73.

Kurniawati, D., Jasaputra, D. K., Dewi, K., Sujatno, M., Putra, M. S., Sallyvania, M. Y.,
\& Juanda, I. J. (2010). Effect of physalis minina,linn., psidium guajana, linn., sweitenia mahgoni, jacq ethanol extract against bood glucose level. Jurnal Mediaka Planta, 1(2), 56-60.

Mangkoewidjojo. (1988). Pemeliharaan, pembiakan, dan penggunaan hewan percobaan di daerah tropis. Jakarta: UI Press.

Marianne, Yuandani, \& Rosnani. (2011). Antidiabetic activity from ethanol extract of kluwih's leaf (artocarpus camansi). Jurnal Natural, 11(1), 64-68.

Mei, D. H., \& Suyatna, F. D. (2006). Efek hipoglikemik daging buah mahkota dewa (phaleria macrocarpa (scheff) boerl.) terhadap kadar gula darah pada manusia sehat setelah pembebanan glukosa. Jurnal Universitas Medicina, 3(25), 114-120.

Middleton, E. J., Kandaswarni, C., \& Theoharides, T. C. (2000). The effect of plant flavonoids on mammalian cell: Inplication, heart disease, and cancer. Pharmacological Reviews, 52, 673-751.

Monica, F. (2006). Pengaruh pemberian air seduhan serbuk biji alpukat (persea americana mill) terhadap kadar glukosa darah tikus wistar yang diberi beban glukosa. Universitas Diponegoro, Semarang.

Nugroho, A. E. (2006). Hewan percobaan diabetes melitus: Pathology mekanisme aksi diabetogenik. Biodiversitas, 7(4), 381-389.

Putri, A. (2015). Pemanfaatanekstrakbijialpukat (persea americana mill.) sebagai antidiabetes. Skripsi Program Studi Pendidikan Kimia FKIP Universitas Tadulako, Palu.

Radiansah, R. (2013). Ekstrak daun kelor (moringa oleifera) sebagai alternatif untuk menurunkan kadar gula darah pada mencit. Skipsi Program Studi Pendidikan Kimia FKIP Universitas Tadulaku, Palu.

Ranakusuma, B. (1987). Diabetes mellitus tenang menghanyutkan. Jakarta: Penebar Swadaya.

Salam, A. A. (2011). Uji efektifitas daun lere (Ipomea pes-caprae (L) roth br.) sebagai alternatif untuk menurunkan kadar glukosa darah kelinci (oryctologus cuniculus). Skripsi 
Universitas Tadulako, Palu.

Sudoyo, W., Setiyohadi, B., Simadibrata, M., \& Setiati, S. (2006). Buku ajar ilmu penyakit dalam jilid III edisi IV. jakarta: Buku Kedokteran EGC.

Verma, M., Paneri , S., \& Raman, P. (2006). Effect of increasing duration of diabetes mellitus type 2 on glycated hemoglobin and insulin sensitivity. Indian journal of clinical biochemistry, 21(1), 142-146.

Yani, W. (2014). Pengaruh ekstrak daun thespesia populnea (L.) soland ex correa terhadap kadar glukosa darah mencit terinduksi aloksan dan profil klt fraksi aktif., Universitas Bengkulu, Bengkulu. 